\title{
Post-Traumatic Pneumoscrotum: Case Report
}

\author{
Post Travmatik Pnömoskrotum: Olgu Sunumu
}

\author{
Kemal Peker ${ }^{1}$, Huriye Güllü², Murat Şahin², Ahmet Issın³ \\ 'Department of General Surgery, Faculty of Medicine, Erzincan University, Erzincan, Turkey \\ 2Department of Anesthesiology and Reanimation, Faculty of Medicine, Erzincan University, Erzincan, Turkey \\ ${ }^{3}$ Department of Orthopedics and Traumatology, Faculty of Medicine, Erzincan University, Erzincan, Turkey
}

\section{ABSTRACT}

Pneumoscrotum is a rare pathology that has received little attention in the literature, although a few cases have been presented with different causes. Etiological factors that can cause pneumoscrotum include the lungs, retroperitoneal sources, surgical procedures or infections with microorganisms producing gas. A 57-year-old man was admitted to the emergency department following a motorcycle accident. He had chest excoriations and a painless crepitant scrotum. In conclusion, subcutaneous emphysema of the scrotum due to traumatic pneumothorax is not an urgent condition and assessment should be supportive with intervention directed at the etiology.

Keywords: Scrotum, subcutaneous emphysema, pneumothorax Received: 04.09.2012 Accepted: 08.01.2013

Available Online Date: 20.05.2013

\section{ÖZET}

Pnömoskrotum literatürde az ilgi gösterilmiş nadir bir patolojidir ve değişik nedenlerle ilişkilendirilmiş az sayıda olgu sunumu mevcuttur. Pnömoskrotuma neden olabilecek etiyolojik faktörler; akciğerler, retroperitoneal kaynaklı cerrahi işlemler ya da gaz üretimi yapabilen mikroorganizmalar ile oluşan enfeksiyonları kapsamaktadır. Motorsiklet kazası sonucu gelişen ağrı ve nefes darlığı şikayetleri ile müracat eden 57 yaşında erkek hasta acil serviste değerlendirildi.Yapılan fizik muayenede sağ kot fraktürüne bağlı gelişen yaygın cilt altı amfizemi ile birlikte sağ testiste ağrısız krepitasyon hali mevcuttu. Sonuç olarak pnömothoraks'a sekonder gelişen pnömoskrotum acil bir durum değildir ve yapılacak olan tedavi etyolojik nedene yönelik olmalıdır.

Anahtar Kelimeler: Skrotum, subkutan amfizem, pnömotoraks Geliş Tarihi: 04.09.2012 Kabul Tarihi: 08.01.2013 Çevrimiçi Yayın Tarihi: 20.05.2013

\section{Introduction}

Subcutaneous scrotal emphysema, also known as pneumoscrotum, is an increase in volume caused by air accumulated in the scrotal sac (1). There are three ways to explain the phenomenon of pneumoscrotum: subcutaneous or retroperitoneal air that dissects into the dartos lining of the scrotal wall, local gas production or air introduction, and movement of air from the intraperitoneal space into the scrotum. Local air production usually suggests serious pathology such as gas gangrene, requiring urgent surgical intervention (2).

\section{Case Report}

A 57-year-old man was admitted to the emergency department following a motorcycle accident. He had excoriations on chest and a painless crepitation was observed in the scrotum (Figure 1).

Palpation of the scrotum gave the characteristic impression of palpating "snow". The testicles were non-palpable. Clinical examination revealed dyspnea. Auscultation of the lungs was suggestive for pneumothorax. The CT imaging study demonstrated a right pneumothorax (Figure 2).

Subcutaneous emphysema, which resulted from the pneumothorax, had expanded into the scrotum (Figure 3).

A right hemothorax and fractures of four of ribs were also diagnosed. There were no other coexisting pathologies of the genitalia. A chest drainage tube was inserted and the patient was consulted in the thoracosurgery clinic for further assessment. 


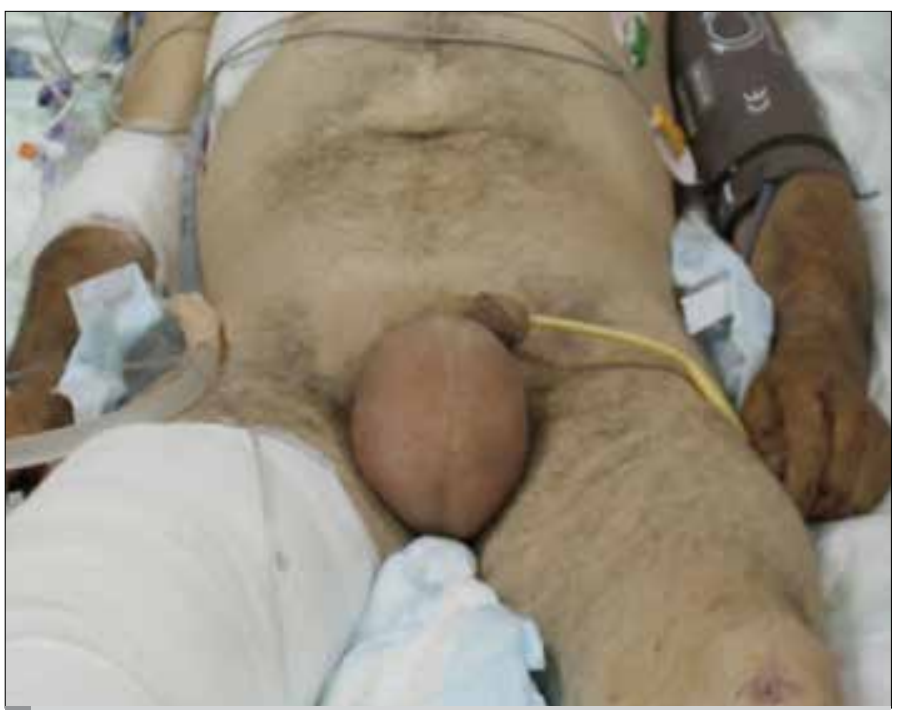

Figure 1. Scrotum with subcutaneous emphysema (pneumoscrotum)

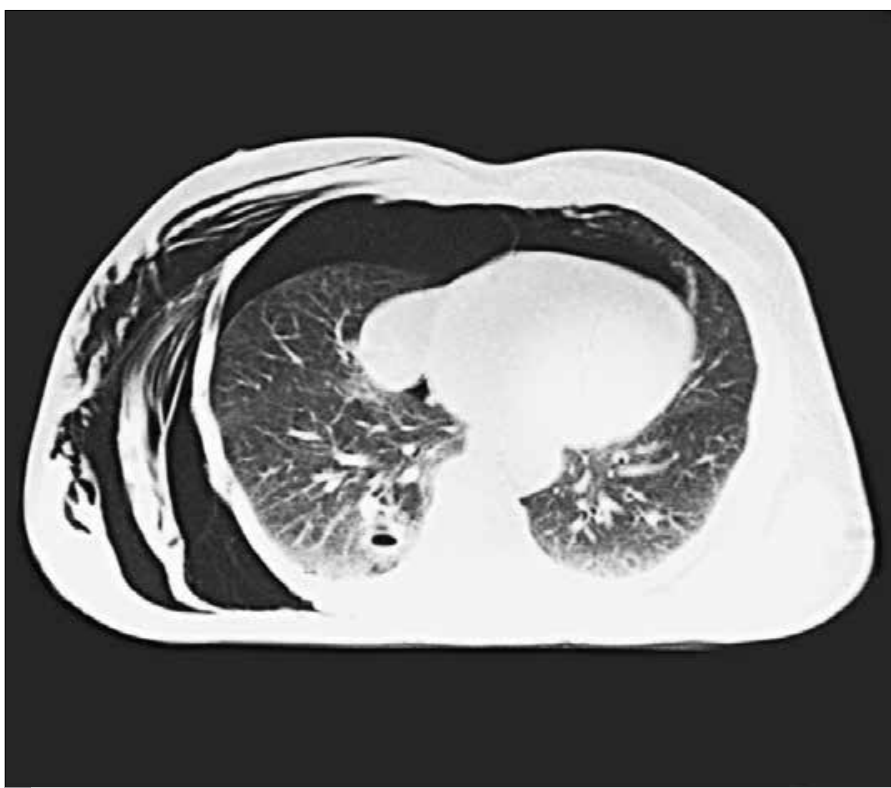

Figure 2. CT cross-section view of subcutaneous emphysema and right-sided pneumothorax

The pneumothorax was partially absorbed and further control was arranged on an outpatient basis. Four weeks after the accident, no air was found in the ultrasound imaging of the scrotum.

\section{Discussion}

Pneumoscrotum has been known since 1962 (3). Archer pointed out that emphysema was the cause of scrotal volume increase in pneumoscrotum due to accumulation within the tunica vaginalis. Pneumoscrotum is an extremely rare occurrence that has several etiologies. It is important to differentiate pneumoscrotum from other causes of acute scrotum, as it may be due to a serious pathology and may require medical or surgical intervention (4). The finding of air in the scrotal sac may be an early sign of a life-threatening condition or may represent an incidental finding associated with more benign conditions (5). The variety of possible etiologies of this rare condition include air accumulation from the lung or retroperitoneal sources, surgical manipulations, or infection with gas-producing organisms.

Making a distinctive diagnosis of pneumoscrotum is significant and it determines the selection of treatments to be carried out. Air in the scrotum can be an early symptom of a life-threatening pathology or the result of a benign pathology. Pneumoscrotum as a result on an infection can cause death unless it is treated appropriately. On the other hand, air flow from the peritoneal area to the scrotum is not usually infectious and can be treated through conservative methods (6). The criteria for conservative management are that the vital symptoms of patient are stable, the stomachache is dull or localized, and the pneumoscrotum is painless or is caused by pneumoperitoneum (7). In our case, conservative treatment was conducted because of the fact that vital symptoms were stable. This pneumoscrotum was the result of a pneumothorax; localized sub-quadrants were sensi-

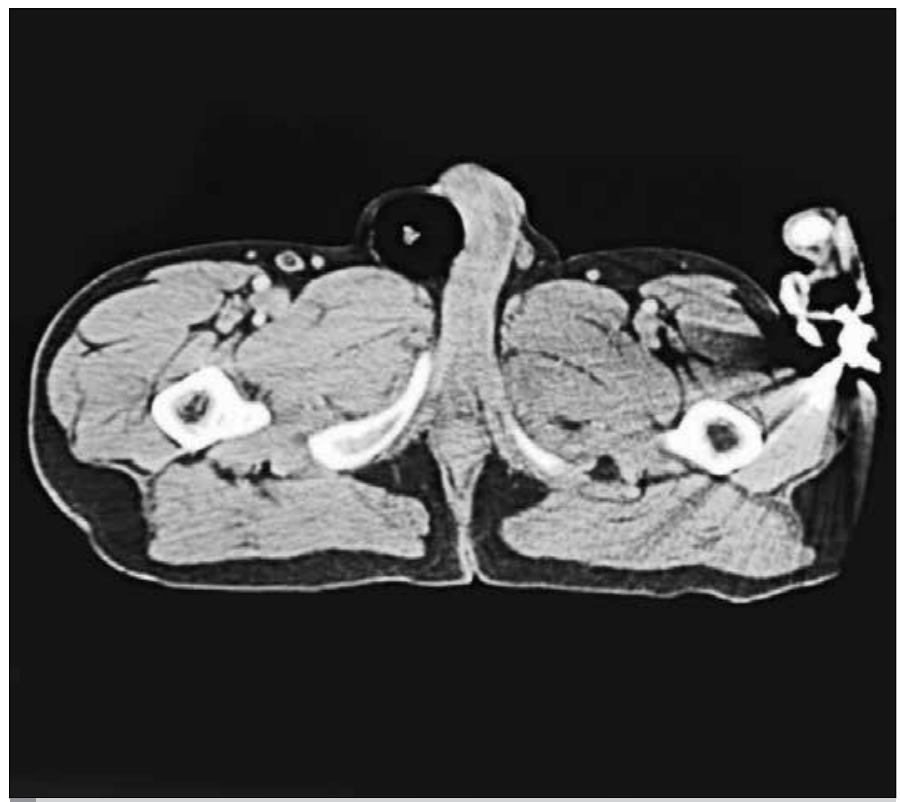

Figure 3. Disclosed free air in the scrotum shown by computed abdominal tomography

tive and they showed neither rebound nor defense responses, and the pneumoscrotum was painless.

\section{Conclusion}

We have presented the first case of pneumoscrotum that developed secondary to thorax trauma in the national literature. Since this is a rare occurrence, it should be noted that the conditions in which true diagnosis and treatment cannot be conducted may cause fatal results.

\section{Conflict of Interest}

No conflict of interest was declared by the authors.

Peer-review: Externally peer-reviewed. 


\section{Author Contributions}

Concept - K.P., H.G.; Design - K.P.; Supervision - K.P.; Funding - K.P.; Materials - K.P., H.G., A.l.; Data Collection and/or Processing - K.P., H.G., M.Ş.; Analysis and/or Interpretation - K.P.; Literature Review - K.P., H.G., M.Ş.; Writer - K.P.; Critical Review - K.P., H.G., M.Ş., A.I.

\section{Çıkar Çatışması}

Yazarlar herhangi bir çıkar çatışması bildirmemişlerdir.

Hakem değerlendirmesi: Dış bağımsız.

\section{Yazar Katkıları}

Fikir - K.P., H.G.; Tasarım - K.P.; Denetleme - K.P.; Kaynaklar - K.P.; Malzemeler - K.P., H.G., A.I.; Veri toplanması ve/veya işlemesi - K.P., H.G., M.Ş.; Analiz ve/veya yorum - K.P.; Literatür taraması - K.P., H.G., M.Ş.; Yazıyı yazan - K.P.; Eleştirel İnceleme - K.P., H.G., M.Ş., A.I.

\section{References}

1. Espinosa-Pérez G, Alberto D, Zuviri-González A, Hernández-Beltrán MA, Mateos-Chavolla PJ, Guzmán-Hernández F, et al. Pneumoscrotum in patient with Tracheotomy. Rev Mex Urol 2011; 71: 185-7.

2. Singh $\mathrm{S}$, Thakur M. Pneumoscrotum after colonoscopy. Can J Gastroenterol 2008; 22: 411-3.

3. Simaioforidis V, Kontos S, Fokitis I, Lefakis G, Koritsiadis S. Subcutaneous emphysema of the scrotum (pneumoscrotum) due to traumatic pneumothorax: a case report. Cases J 2008; 1: 293. [CrossRef]

4. Casey RG, Al-Dousari S, Murphy D, Power RE. Chest drain insertion may result in the acute scrotum. Scand J Urol Nephrol 2006; 40: 78-9. [CrossRef]

5. Pezeshki Rad M, Mohammadi Fard M. A Case of Pneumoscrotum Following Chest Tube Placement. Iran J Radiol 2008; 5: 235-7.

6. Sümer A, Tekbaş G, Özerdem S. Pnömoskrotum: Çift Kontrastlı Kolon Grafisinin Nadir bir komplikasyonu. ADÜ Tıp Fakültesi Dergisi 2008; 9: 39-41.

7. Fu Kl, Sano Y, Kato S, Fujii T, Sugito M, Ono M, et al. Pneumoscrotum: a rare manifestation of perforation associated with therapeutic colonoscopy. World J Gastroenterol 2005; 11: 5061-3. 